\title{
FEEDING WHEAT DISTILLERS DRIED GRAINS WITH SOLUBLES (DDGS) TO LAYING HENS AND ITS EFFECT ON PERFORMANCE AND EGG QUALITY*
}

\author{
Jan Niemiec ${ }^{1}$, Julia Riede ${ }^{1}$, Tadeusz Szulc ${ }^{2}$, Małgorzata Stępińska \\ ${ }^{1}$ Department of Poultry Breeding, Warsaw University of Life Sciences, ul. Ciszewskiego 8, \\ 02-786 Warsaw, Poland \\ ${ }^{2}$ Institute of Animal Breeding, Wrocław University of Environmental and Life Sciences, \\ Chełmońskiego 38 c, 51-630 Wrocław, Poland \\ Corresponding author: jan.niemiec@sggw.pl
}

\begin{abstract}
The purpose of this experiment was to determine the effect of wheat DDGS as a feed ingredient on the performance of laying hens and their egg quality. ISA Brown laying hens were administered a feed mixture containing $15 \%$ (E1) or $20 \%$ (E2) wheat DDGS for 12 weeks. The hens from the control group $(C)$ received a standard diet based on soybean meal as the main protein source only. Laying performance (laying \%), average egg weight (g), average daily feed intake (g/hen), and feed conversion ratio ( $\mathrm{kg} / \mathrm{kg}$ eggs) were recorded over the study period. Egg quality traits (egg weight, thick albumen quality, yolk colour, yolk percentage, shell percentage and shell thickness) were evaluated twice: before the start and at the end of the experiment. There was no effect of dietary DDGS on laying performance or on feed intake. The average egg weight was significantly lower in both experimental groups and the feed conversion ratio was lower compared to the control group. Dietary wheat DDGS did not affect the main egg quality parameters except for thick albumen quality. Eggs from hens fed the diet with DDGS had higher values of Haugh unit than those from the control hens. These results suggest that wheat DDGS can be used in amounts of up to $20 \%$ as a component of feed mixtures for flocks of laying hens.
\end{abstract}

Key words: DDGS, wheat, laying hens, egg production, egg quality

Distillers dried grains with solubles (DDGS) are a distillation waste product, but in animal nutrition they can be a valuable plant protein raw material. According to Brzóska (2004), the production of 225 million litres of raw spirit enables obtaining 180-200 thousand tons of DDGS, which can replace $10-15 \%$ of soybean meal. In North America corn is the major raw material used in the production of DDGS. In our climatic zone, these could also be native cereal grains (Koreleski and Świątkiewicz, 2007; Cozannet et al., 2010).

\footnotetext{
*Author's project of the State Committee for Scientific Research, project no. R12 05903.
} 
The nutritional value of DDGS varies depending on the quality of the base material and its formulation (Cozannet et al., 2010). Usually, it is three times higher compared with the raw material except for metabolizable energy, the content of which diminishes after starch extraction (Spiehs et al., 2002; Koreleski and Świątkiewicz, 2007). This prompts the need to take an account of the nutritional value of particular batches of DDGS when balancing the nutritional value of feed.

The purpose of this experiment was, therefore, to investigate the feasibility of applying wheat DDGS left after the production of ethanol as a substitute for soybean meal fed to laying hens, and to determine the effect of wheat DDGS as a feed ingredient on the performance of laying hens and their egg quality.

\section{Material and methods}

The study was conducted on 144 ISA Brown laying hens at the age of 40 weeks at the onset of the experiment. The study was carried out over 12 weeks (20-31 weeks of production). The layers were kept in individual cages of a three-tier battery. Lighting programme and temperature in the building were according to the ISA Brown Management Guide (www.hendrix-genetics.com, 2008 b). These conditions were the same as before the experiment.

The experiment was conducted in three feeding groups with 48 hens per group: E1 and E2 (experimental) and C (control). Both experimental groups received a feed mixture containing $15 \%$ (E1) or $20 \%$ (E1) of wheat DDGS as a replacement for part of soybean meal. The hens from the control group (C) were given a standard laying diet based on soybean meal as the main protein source only. Control feed was the same as that fed to hens before the experiment. The composition of feed mixtures and their nutritional value are presented in Table 1.

Feed formulas were prepared by the Feed Production Plant in Baniocha based on its raw materials accepted as the standard feed. Experimental feed formulas were developed taking into account the result of the proximate analysis of wheat DDGS (Tables 2 and 3). All the other components, including the humin preparation, used in feeds were the same as in the standard feed produced by this manufacturer.

The chemical composition was determined according to AOAC methods (AOAC, 2005). Amino acid analyses were performed with a Beckman high pressure AA analyser System Gold (Beckman Instruments, Inc. Fullerton, CA, USA) after acid hydrolysis, methionine and cystine after oxidation with performic acid, and tryptophan after hydrolysis with barium hydroxide (Buraczewska and Buraczewski, 1984).

All birds were individually weighed just before the start (40 weeks of age) and at the end of the experiment (51 weeks of age).

Daily egg production, daily egg weight and weekly feed intake were noted in each group in each successive week. Based on this data, calculations for each week were performed for laying performance (laying percentage), average egg weight ( $\mathrm{g}$ ), egg production per hen per day ( $g$ ), average daily feed intake ( $g$ per hen), and feed conversion ratio ( $\mathrm{kg}$ of feed per $\mathrm{kg}$ of egg weight). The total egg mass $(\mathrm{kg})$ produced in each group during the study was also calculated. 
Table 1. Composition (\%) and nutritional value of feed mixtures used in the experiment

\begin{tabular}{|c|c|c|c|}
\hline \multirow{2}{*}{ Item } & \multicolumn{3}{|c|}{ Content in diet $(\%)$} \\
\hline & Group C & Group E1 & Group E2 \\
\hline \multicolumn{4}{|l|}{ Ingredients: } \\
\hline corn & 16.00 & 16.00 & 16.00 \\
\hline wheat & 41.08 & 38.03 & 35.81 \\
\hline wheat bran & 8.00 & 2.00 & 2.00 \\
\hline soybean meal & 19.94 & 12.00 & 9.00 \\
\hline wheat DDGS & & 15.00 & 20.00 \\
\hline soybean oil & 1.06 & 2.50 & 2.90 \\
\hline monocalcium phosphate & 1.10 & 1.26 & 1.26 \\
\hline $\mathrm{CaCO}_{3}$ & 9.80 & 10.00 & 9.80 \\
\hline lysine & 0.01 & 0.15 & 0.18 \\
\hline methionine & 0.11 & 0.10 & 0.09 \\
\hline threonine & & 0.04 & 0.04 \\
\hline salt & 0.40 & 0.42 & 0.42 \\
\hline vitamin-mineral premix $*$ & 1.00 & 1.00 & 1.00 \\
\hline humobentofet $* *$ & 0.50 & 0.50 & 0.50 \\
\hline humokarbowit $* *$ & 1.00 & 1.00 & 1.00 \\
\hline \multicolumn{4}{|l|}{ Nutritional value: } \\
\hline $\mathrm{ME} \mathrm{MJ/kg}$ & 11.31 & 11.32 & 11.27 \\
\hline total protein $(\%)$ & 16.40 & 16.46 & 16.46 \\
\hline crude fibre $(\%)$ & 3.53 & 4.55 & 5.03 \\
\hline total $\mathrm{Ca}(\%)$ & 4.14 & 4.20 & 4.11 \\
\hline $\mathrm{P}$ available $(\%)$ & 0.39 & 0.39 & 0.38 \\
\hline Lysine (\%) & 0.795 & 0.808 & 0.793 \\
\hline Methionine $(\%)$ & 0.408 & 0.412 & 0.406 \\
\hline Methionine + Cystine (\%) & 0.703 & 0.750 & 0.759 \\
\hline Threonine (\%) & 0.580 & 0.586 & 0.575 \\
\hline Tryptophan (\%) & 0.200 & 0.135 & 0.114 \\
\hline Linoleic acid (\%) & 1.186 & 1.992 & 2.215 \\
\hline
\end{tabular}

* Standard 1.0\% mineral-vitamin premix for laying hens: vitamin A - $1350000 \mathrm{IU}$; vit. $\mathrm{D}_{3}-300000 \mathrm{IU}$; vitamin $\mathrm{E}-3500 \mathrm{mg}$; vitamin $\mathrm{K}-250 \mathrm{mg}$; vitamin $\mathrm{B}_{1}-250 \mathrm{mg}$; vitamin $\mathrm{B}_{2}-800 \mathrm{~m}$; vitamin $\mathrm{B}_{6}-300 \mathrm{mg}$; vitamin $\mathrm{B}_{12}-3000 \mathrm{mcg}$; biotin - $25000 \mathrm{mcg}$; pantothenic acid - $1200 \mathrm{mg}$; nicotinic acid - $2500 \mathrm{mg}$; folic acid - 150 mg; choline - 35000 mg; Fe - 5000 mg; Cu - 800 mg; Zn - 7500 mg; Mn - 8000 mg; J - 100 mg; Se $30 \mathrm{mg}$; Co $-40 \mathrm{mg} ; \mathrm{Mg}-10 \mathrm{~g} ; \mathrm{Ca}-300 \mathrm{~g}$; antioxidant $-500 \mathrm{mg}$.

** Humic preparations containing humic and fulvic acids, phytohormones and phytoenzymes, trace minerals and trace elements.

Table 2. Nutritional value of wheat DDGS (data from feed analysis)

\begin{tabular}{lcc}
\hline \multicolumn{1}{c|}{ Nutritional value } & Content $(\%)$ \\
\hline Dry matter & 95.21 \\
Total protein & 32.65 \\
Crude fat & 5.29 \\
Crude fibre & 14.64 \\
Crude ash & 2.16 \\
ME MJ/kg * & 8.474 \\
\hline
\end{tabular}

*Calculated by method of Smulikowska (1996). 
Table 3. Amino acid content in wheat DDGS ( $\mathrm{g} / 16 \mathrm{~g} \mathrm{~N}$ or $\mathrm{g} / 100 \mathrm{~g}$ protein)

\begin{tabular}{lc}
\hline ASP & 5.44 \\
THR & 3.11 \\
SER & 4.83 \\
GLU & 33.23 \\
PRO & 8.54 \\
GLY & 4.01 \\
ALA & 4.08 \\
VAL & 4.62 \\
ILE & 3.80 \\
LEU & 7.51 \\
TYR & 2.41 \\
PHE & 4.61 \\
HIS & 2.17 \\
LYS & 3.05 \\
ARG & 4.83 \\
CYS & 2.56 \\
MET & 1.73 \\
\hline
\end{tabular}

Just before the start ( 40 weeks of age) and at the end of the experiment (51 weeks of age) all daily laid eggs from each group were collected. Eggs were subjected to standard quality control with the use of EQM system, version 1.0. Parameters estimated in fresh eggs on both dates were egg weight (g), thick albumen quality (Haugh units), yolk colour (Roche colour fan), yolk content in egg (\%), and shell thickness $(\mathrm{mm})$. In order to determine dry egg shell percentage, the shells were cleaned and dried for $24 \mathrm{~h}$ at $110^{\circ} \mathrm{C}$.

The data for each trait were analysed by one-way analysis of variance calculated by the least squares method, separately for different factors: group and age (SPSS 14.0, GLM procedure).

\section{Results}

Over the experimental period, no deaths were recorded in any of the groups compared. Both at the beginning and at the end of the experiment, average body weight of layers in all groups was similar (Table 4), and the significance of differences between the groups was not confirmed statistically on any of the dates. The average body weight gain of hens during the experiment decreased with the increasing proportion of wheat DDGS in the feed $(\mathrm{C}-91 \mathrm{~g}, \mathrm{E} 1-79 \mathrm{~g}, \mathrm{E} 2-63 \mathrm{~g})$. It can thus be concluded that the dietary inclusion of DDGS slightly reduced weight gain in the hens. In all groups hens were significantly heavier at the end of the experiment when compared to the beginning (Table 4).

Shown in Figure 1 is the hens' laying production, with minor deviations, which was maintained in all groups within the standard for this line of laying hens (www. hendrix-genetics.com, 2008a), but the results reported in Table 5 indicate slightly 
lower laying performance in group E2 (difference not significant), which was fed a diet containing 20\% DGGS. Pronounced differences occurred in the egg weight (Figure 2). The average egg weight in the control group (except for weeks 2 and 4 of the experiment) was always above the standard, while the group fed a diet containing DDGS was below the standard for ISA Brown hens, and the differences between the control and experimental groups were statistically significant $(\mathrm{P} \leq 0.01)$ (Table 5). Nonetheless, the content of DDGS in the feed was irrelevant. A similar trend was observed with regard to egg mass per hen per day, and the total egg mass $(\mathrm{kg})$ produced during the study decreased with the increasing proportion of wheat DDGS in the feed $(\mathrm{C}-231.7 \mathrm{~kg}, \mathrm{E} 1-227.9 \mathrm{~kg}, \mathrm{E} 2-223.9 \mathrm{~kg})$. The dietary inclusion of DDGS did not affect daily feed intake, which is consistent with the observations of Masa'deh et al. (2011), but feed conversion ratio per kg of egg weight was significantly $(\mathrm{P} \leq 0.01)$ higher in the control group compared to the other groups.

Table 4. Hens' body weight ( $\mathrm{g}$ ) before the start and after the end of experiment

\begin{tabular}{l|c|c|c|c|c|c}
\hline \multirow{2}{*}{ Group } & \multicolumn{2}{|c|}{$\begin{array}{c}\text { Body weight at the start } \\
\text { of experiment (g) }\end{array}$} & $\begin{array}{r}\text { Body weight at the end of } \\
\text { experiment }(\mathrm{g})\end{array}$ & Gain (g) & $\begin{array}{c}\text { Significance } \\
\text { of differences }\end{array}$ \\
\cline { 2 - 5 } & LSM & SE & LSM & SE & & $* *$ \\
K & 1713 & 22.5 & 1804 & 19.8 & 91 & $* *$ \\
D1 & 1685 & 22.5 & 1764 & 19.8 & 79 & $*$ \\
\hline
\end{tabular}

Values in rows - non significant differences.

Values in columns differ significantly: ** at $\mathrm{P} \leq 0.01 ; *$ at $\mathrm{P} \leq 0.05$.

$(\%)$

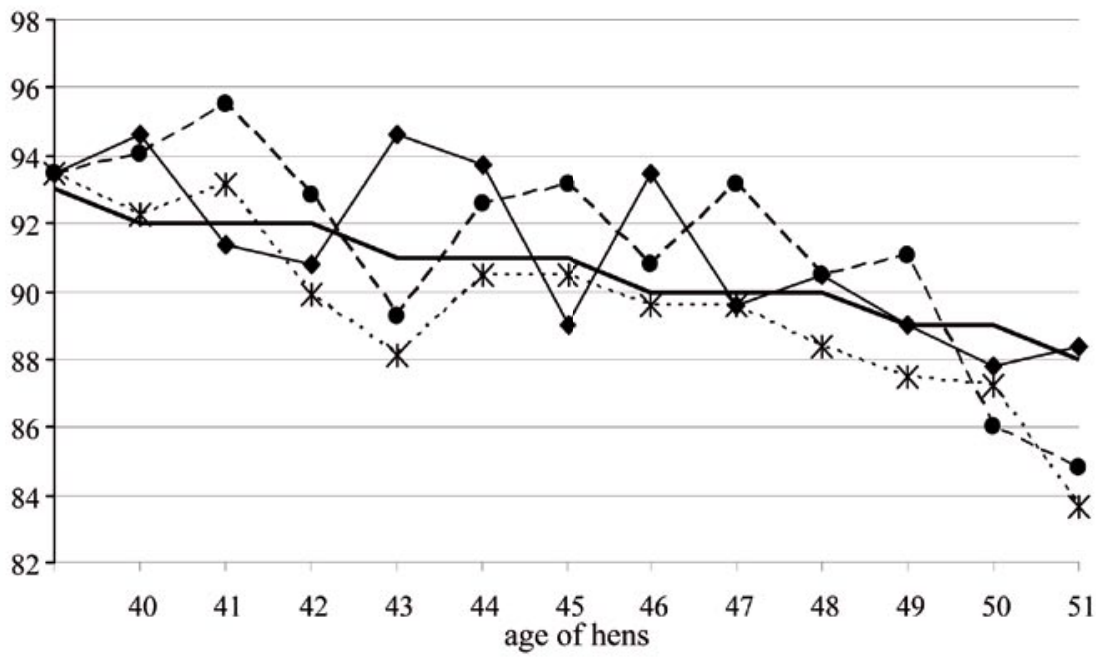

Figure 1. ISA Brown laying production (\%) over the experimental period 
Table 5. Production results over the period of 12 weeks

\begin{tabular}{l|c|c|c|c|c|c}
\hline \multicolumn{1}{c|}{ Parameters } & \multicolumn{2}{c|}{ Group C } & \multicolumn{2}{c|}{ Group E1 } & \multicolumn{2}{c}{ Group E2 } \\
\hline \multicolumn{1}{c|}{ Number of hens } & \multicolumn{2}{c|}{48} & \multicolumn{2}{c}{48} & \multicolumn{2}{c}{48} \\
\hline & LSM & SE & LSM & SE & LSM & SE \\
\hline Laying percentage & 91.1 & 0.76 & 91.1 & 0.76 & 89.2 & 0.76 \\
Mean egg weight (g) & $63.4 \mathrm{~A}$ & 0.19 & $62.0 \mathrm{~B}$ & 0.19 & $62.3 \mathrm{~B}$ & 0.19 \\
Egg production (g) per hen per day & $57.7 \mathrm{~A}$ & 0.42 & $56.5 \mathrm{AB}$ & 0.42 & $55.5 \mathrm{~B}$ & 0.42 \\
Feed intake (g) per hen per day & 113.5 & 42.03 & 113.6 & 42.03 & 113.8 & 42.03 \\
Feed conversion per kg egg weight $(\mathrm{kg})$ & $1.97 \mathrm{~A}$ & 0.1 & $2.01 \mathrm{AB}$ & 0.1 & $2.05 \mathrm{~B}$ & 0.1 \\
Total egg mass $(\mathrm{kg}) *$ & \multicolumn{2}{c}{232.685} & \multicolumn{3}{c}{227.941} & \multicolumn{3}{c}{223.935} \\
\hline
\end{tabular}

A, B - Values in rows with different letters differ significantly $(\mathrm{P} \leq 0.01)$.

* Data without statistical analysis.

(g)

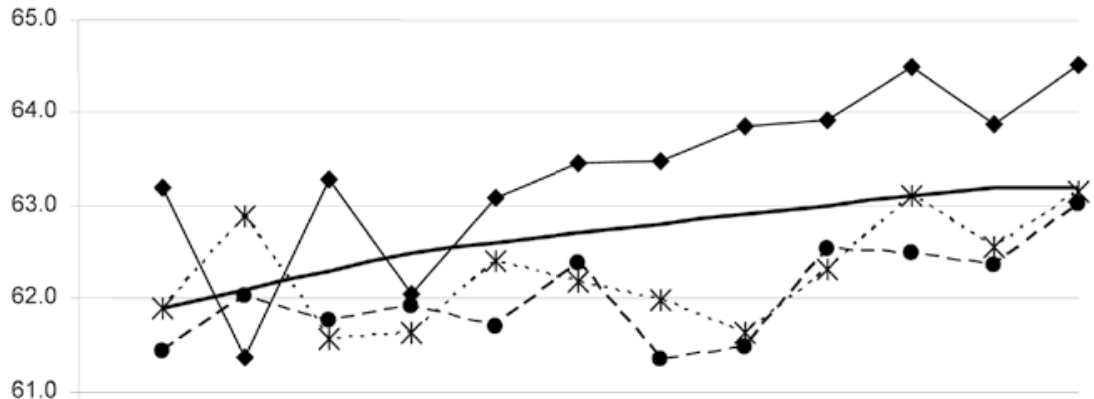

60.0

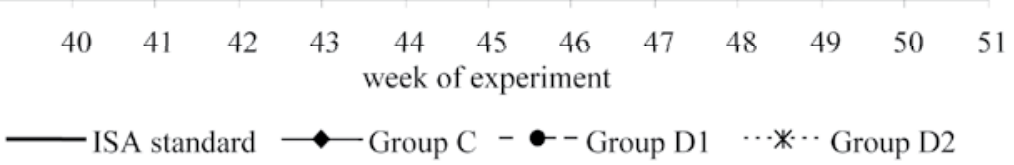

Figure 2. ISA Brown egg weight (g) over the experimental period

Results of the standard evaluation of egg quality before and at the end of the experiment are shown in Table 6. Over the experimental period, egg weight was observed to increase in all groups, yet the increase was not significant. At the end of the experiment there were no statistically significant differences between groups either; however, lower values of this trait in the experimental groups confirmed the results discussed above (Figure 2, Table 5) suggesting the negative impact of dietary DDGS on egg weight.

The quality of thick albumen expressed in Haugh units (HU) decreased during the experiment, and differences between the values in all groups were statistically significant $(\mathrm{P} \leq 0.01)$ (Table 6). The greatest reduction in thick albumen quality about $12.31 \mathrm{HU}$ - was recorded in the control group, while in groups E1 and E2 the values were lower, i.e. 8.18 and $8.10 \mathrm{HU}$, respectively. On the second date of evalu- 
ation, in the groups fed a diet containing DDGS the thick albumen quality was better, and the differences between the control and experimental groups were statistically significant $(\mathrm{P} \leq 0.01)$ (Table 6).

Table 6. Egg quality parameters analysed on two dates: before the experiment (date I) and at the end of the experiment (date II)

\begin{tabular}{|c|c|c|c|c|c|c|c|c|}
\hline \multirow[b]{2}{*}{ Trait } & \multirow[b]{2}{*}{ Group } & \multicolumn{3}{|c|}{ Date I } & \multicolumn{3}{|c|}{ Date II } & \multirow{2}{*}{$\begin{array}{c}\text { Significant } \\
\text { differences } \\
\text { between } \\
\text { dates }\end{array}$} \\
\hline & & $\mathrm{n}$ & LSM & SE & $\mathrm{n}$ & LSM & SE & \\
\hline Egg & $\mathrm{C}$ & 46 & 61.59 & 0.68 & 45 & 63.18 & 0.80 & NS \\
\hline weight & E1 & 44 & 59.27 & 0.69 & 39 & 61.15 & 0.86 & NS \\
\hline (g) & E2 & 45 & 60.10 & 0.68 & 38 & 61.91 & 0.87 & NS \\
\hline Thick & $\mathrm{C}$ & 46 & 86.83 & 1.18 & 45 & $74.52 \mathrm{a}$ & 1.35 & $* *$ \\
\hline albumen & E1 & 44 & 87.57 & 1.21 & 39 & $79.39 \mathrm{~b}$ & 1.45 & $* *$ \\
\hline quality (HU) & E2 & 45 & 85.63 & 1.19 & 38 & $78.59 \mathrm{~b}$ & 1.47 & $* *$ \\
\hline Yolk & $\mathrm{C}$ & 46 & 10.26 & 0.13 & 45 & 5.16 & 0.08 & $* *$ \\
\hline colour & E1 & 44 & 10.21 & 0.13 & 39 & 5.23 & 0.09 & $* *$ \\
\hline (RCF) & E2 & 45 & 10.31 & 0.13 & 38 & 5.34 & 0.09 & $* *$ \\
\hline Yolk & $\mathrm{C}$ & 46 & 24.65 & 0.25 & 45 & 25.92 & 0.29 & $* *$ \\
\hline content & E1 & 44 & 24.96 & 0.26 & 39 & 26.50 & 0.32 & $* *$ \\
\hline$(\%)$ & E2 & 45 & 25.14 & 0.25 & 38 & 26.36 & 0.32 & $* *$ \\
\hline Shell & $\mathrm{C}$ & 46 & $9.97 \mathrm{a}$ & 0.11 & 45 & 9.85 & 0.13 & NS \\
\hline content & E1 & 44 & $10.38 \mathrm{~b}$ & 0.11 & 39 & 9.78 & 0.14 & $* *$ \\
\hline$(\%)$ & E2 & 45 & $10.34 \mathrm{~b}$ & 0.11 & 38 & 9.70 & 0.14 & $* *$ \\
\hline Shell & $\mathrm{C}$ & 46 & 0.371 & 0.004 & 45 & 0.372 & 0.005 & NS \\
\hline thickness & E1 & 44 & 0.377 & 0.004 & 39 & 0.360 & 0.005 & $* *$ \\
\hline$(\mathrm{mm})$ & E2 & 45 & 0.379 & 0.004 & 38 & 0.359 & 0.005 & NS \\
\hline
\end{tabular}

$\mathrm{a}, \mathrm{b}-$ Values in rows with different letters differ significantly $(\mathrm{P} \leq 0.05)$.

** - Values in columns differ significantly $(\mathrm{P} \leq 0.01)$; NS - non significant difference.

Significant $(\mathrm{P} \leq 0.01)$ differences in the values of both egg yolk quality parameters were determined between eggs assessed before and at the end of the experiment (Table 6). At the end of the experiment egg yolk was significantly lighter in colour than before the study because all experimental feeds did not contain any pigments so as not to influence the results. The egg yolk content increased significantly in all groups during the experiment. However, on neither date were the differences significant between the groups in yolk colour or yolk content of egg.

The quality of egg shells, expressed by their thickness and content in the egg, was good irrespective of the age of laying hens and feed mixture administered to the birds (Table 6). At the beginning of the experiment, chickens from the control group, despite the random selection, were characterized by a significantly $(\mathrm{P} \leq 0.05)$ lower content of the egg shell in comparison with the other groups, while in the second period of evaluation there were no longer any significant differences between the groups compared. In the case of thick shells there were no significant differences on any of the dates. 


\section{Discussion}

Previously conducted studies have not determined the impact of alcohol-distilling brew on the body weight of adult hens, whereas the effect of DDGS was tested for body weight of broiler chickens. However, it is difficult to compare adult hens with broilers. Koreleski and Świątkiewicz (2004) showed that adding 10\% DDGS to the diet led to lower body weight gains in broilers and feed efficiency deterioration. Similar trends were also reported in layers.

The observed small and non-significant reduction in laying capacity in the group with $20 \%$ wheat DDGS is consistent with previous findings. A review by Świątkiewicz and Koreleski (2008) cites a study in which a $20 \%$ proportion of wheat or barley DDGS had no effect on performance in laying hens. However, the authors quoted above emphasize that the application of DDGS used as a substitute for soybean protein required balancing the essential amino acids by supplementing them with synthetic equivalents, and this concerns mainly lysine. Dale and Batal (2003) point out that the administration of a feed with a slightly lower level of energy but with DDGS may lead to a slight reduction in egg laying. The laying diets containing more than $20 \%$ corn DDGS reduced the average values of egg production reported by Ghazalah et al. (2011).

Increased linoleic acid content in experimental feeds should increase the weight of eggs (Sauveur, 1988), but this was not observed in the present experiment. In most studies conducted around the world use was made of corn DDGS. Jensen et al. (1978) and Dale and Batal (2003) found no impact of DDGS on egg weight. However, Roberson et al. (2005) reported that in some periods of the experiment the mass of eggs laid in groups receiving dietary DDGS was slightly lower than in the control group. Masa'deh et al. (2011) found that increasing corn DDGS level in the diet beyond $15 \%$ caused a reduction in weight of eggs laid between 24 and 47 week of age. Also Ghazalah et al. (2011) reported decreasing egg mass after replacing yellow corn with $20 \%$ DDGS. On the other hand, the administration of DDGS derived from rye yielded negative effects on the daily mass of egg production and feed efficiency per egg (Świątkiewicz and Koreleski, 2007).

When discussing the effect of feeding DDGS to hens on egg quality, attention should be paid to the simultaneous operation of two factors: experimental feed and age of hens, which independently affect the quality of egg production. The typical changes that appear in the quality of eggs as a result of increased age are growth of the egg and yolk mass and deterioration in quality of thick albumen and egg shell (Sauveur, 1988). Since this pattern was found in all feeding groups, the changes observed in egg quality can be clearly ascribed to the age of hens (Table 6). We can therefore conclude that the age of laying hens affects the quality of eggs. Yolk colour, on the other hand, is a characteristic determined solely by the content and type of pigments in the feed (Sauveur, 1988). The evaluation of egg quality before the start of the experiment was performed in all groups of hens when they were still fed a standard feed containing a pigment that assured yolk colour of $>9$ points on the Roche colour fan, while the experimental feed contained pigments originating exclusively from the feed components. This is the 
reason why egg yolk was significantly less stained at the end of the experiment (Table 6).

The higher HU values (compared with group C) identified at the end of the study in the experimental groups clearly indicate a positive effect of wheat DDGS. The increase in Haugh units when the hens were administered the DDGS diet was reported earlier by Jensen et al (1978) and Sauveur (1988), all of whom considered that the products of fermentation of grains added to the feed contributed positively to the quality of thick albumen. According to these authors, this is the likely effect of increased amounts of micronutrients. However, Lumpkins et al. (2005) did not confirm this effect.

The lack of significant differences in the colour of egg yolks evaluated at the end of the experiment indicates that wheat DDGS (which are not a source of pigment) did not affect this trait. Although Roberson et al. (2005) and Masa'deh et al. (2011) have demonstrated a beneficial effect of dietary DDGS on egg yolk colour, a study by Lumpkins et al. (2005) did not confirm it. However, in their study the authors used wheat DDGS rather than corn DDGS.

The egg shell contribution to egg mass was slightly lower compared to the values found in literature, for the shell weight was determined after drying, while in other works the weight of fresh shells was accepted as the baseline value (Table 6). A significant $(\mathrm{P} \leq 0.01)$ decrease of egg shell in egg weight due to the ageing of hens in the experimental groups was not observed in group $\mathrm{C}$, which suggests the negative impact of dietary DDGS on the quality of the shell, all the more so because a similar, though less clear relationship was reported for the thickness of the shell (the difference between the dates significant at $\mathrm{P} \leq 0.01$ only in group E1). Similarly, previous studies by Dale and Batal (2003), Roberson et al. (2005) and Świątkiewicz and Koreleski (2008) have shown no significant influence of dietary inclusion of DDGS on the quality of egg shells.

The results obtained indicate that wheat DDGS can be used in amounts of up to $20 \%$ as a component of feed for flocks of laying hens. However, it should be noted that the nutritional value of DDGS varies and should thus be taken into account when formulating feeds.

\section{References}

AOAC (2005). Official Methods of Analysis of AOAC, International 16th Edition. Association of Analytical Chemists, Arlington, VA, USA.

Brzóska B. (2004). Pasze uboczne uzyskiwane z produkcji biopaliw i ich znaczenie w bilansie paszowym kraju. Mat. Konf. Wykorzystanie produktów pochodnych wytwarzania biopaliw w gospodarce paszowej I żywieniu zwierząt. Wyd. IZ Kraków, pp. 5-14.

Buraczewska L., Buraczewski S. (1984). A note on determination of methionine and tryptophan. In: Proceedings of 6th International Symposium on Amino Acids. Serock (Poland). Polish Scientific Publishers. Warszawa, pp. 47-50.

Cozannet P., Less ire M., Gady C., Metayer J.P., Primot Y., Skiba F., Noblet J. (2010). Energy value of wheat dried distillers grains with solubles in roosters, broilers, layers and turkeys. Poult. Sci., 89: 2230-2241. 
D a 1 e N., B a ta 1 A. (2003). Nutritional value of distillers dried grains and solubles for poultry. Figures 1, 2, 3. 19th Annual Carolina Nutrition Conf., Research Triangle Park, NC. 30 October 2003, pp. $1-6$.

Ghazalah A.A., Abd-Els a me e M.O., A l-Arami A.A. (2011). Use of distillers dried grains with solubles (DDGS) as replacement for yellow corn in laying hen diets. Egypt. Poult. Sci., 31: 191-202.

J e n s e n L.S., C hang C.H., Wil s o n S.P. (1978). Interior egg quality: Improvement by distillers feeds and trace elements. Poultry Sci., 57: 648-654.

K or e leski J., Ś wi ątki ewicz S. (2004). Nutritive value and use of distillers dried grains with solubles in poultry nutrition. (In Polish). Proc. Conf. on the Use of byproducts from biofuel production in feed management and animal nutrition. Wyd. IZ Kraków: pp. 39-46.

Koreleski J., Ś wi ąt ki ewicz S. (2007). Byproducts from biofuel production - nutritive value and use rapeseed cake/expeller, glycerol and distillers dried grains with solubles in poultry nutrition. (In Polish). Biuletyn Polskiego Związku Producentów Pasz, 54: 21-27.

L u m p k in s B., B a t a 1 A., D a l e N. (2005). Use of distillers dried grains plus solubles in laying hen diets. J. Appl. Poult. Res., 14: 25-31.

Mas a'd eh M.K., Purdum S.E., Hanford K.J (2011). Dried distillers grains with solubles in laying hen diets. Poultry Sci., 90: 1960-1966.

R o ber s o n, K.D., K a lb fle i s h J.L., P a n W., C ha rb e n e a u R.A. (2005). Effect of corn distiller's dried grains with solubles at various levels on performance of laying hens and egg yolk color. Internat. J. Poultry Sci., 4: 44-51, 2005.

S a u ve u r B. (1988). Qualite de l'oeuf, dans Reproduction des Volailles et Production d'Oeufs. Ed. INRA, Paris, pp. 379-436.

Spiehs M.J., Whitney M.H., Shurson G.C. (2002). Nutrient database for distiller's dried grains with solubles produced from new plants in Minnesota and South Dakota. J. Amin. Sci., 80: 2639-2645.

Ś w i ą t k i e w i c z S., K o re les k i J. (2007). Quality of egg shells and bones in laying land fed a diet containing distillers dried grains with solubles. (In Polish). Med. Wet., 63: 99-103.

Ś w i ą t k i e w i c z S., K or e le s k i J. (2008). The use of distillers dried grains with solubles (DDGS) in poultry nutrition. World's Poultry Sci. J., 64: 257-265.

www.hendrix-genetics.com (2008 a). Products, Commercial layer ISA Brown.

www.hendrix-genetics.com (2008 b). Technical Information, Commercial Layers, ISA Brown.

Accepted for printing 21 XI 2011

JAN NIEMIEC, JULIA RIEDEL, TADEUSZ SZULC, MAŁGORZATA STĘPIŃSKA

\section{Zastosowanie pszennego wywaru gorzelnianego (DDGS) w żywieniu kur niosek a wyniki produkcyjne i jakość jaj}

\section{STRESZCZENIE}

Celem doświadczenia było określenie wpływu pszennego wywaru gorzelnianego zastosowanego jako składnik paszy dla niosek na wydajność nieśną kur i jakość jaj. Kury nioski ISA Brown przez 12 tygodni były żywione mieszanką zawierającą 15\% (E1) i 20\% (E2) wywaru pszennego. Kury z grupy kontrolnej (C) otrzymywały typową paszę bez udziału DDGS, w której główne źródło białka stanowiła poekstrakcyjna śruta sojowa. W okresie doświadczenia kontrolowano wydajność nieśną (\% nieśności), średnią masę jaja (g), średnie dzienne spożycie paszy (g/szt./dzień) oraz wykorzystanie paszy (kg/1 kg jaj). Jakość jaj (masa jaja, jakość białka gęstego, kolor żółtka, procent żółtka, procent skorupy i grubość skorupy) oceniano dwukrotnie: przed rozpoczęciem i na koniec doświadczenia. Nie stwierdzono wpływu DDGS w paszy na wydajność nieśną ani na spożycie paszy. Średnia masa jaj była 
istotnie niższa w obydwu grupach doświadczalnych, a zużycie paszy na $1 \mathrm{~kg}$ jaj wyższe w porównaniu do grupy kontrolnej. Udział DDGS w paszy nie wpłynął na główne cechy jakości jaj z wyjątkiem białka gęstego. Jaja od kur żywionych paszą z udziałem wywaru pszennego charakteryzowała wyższa wartość jednostek Haugha niż jaja z grupy kontrolnej. Uzyskane wyniki sugerują, że DDGS z pszenicy w ilości do $20 \%$ może być stosowane jako komponent paszy dla kur niosek. 